\title{
Meningkatkan Hasil Belajar IPS Melalui Model Pembelajaran Scramble Siswa Kelas V SD Pudun Jae pada Materi Keanekaragaman Suku Bangsa dan Budaya Indonesia.
}

\author{
Rahmadani Tanjung* \\ ${ }^{1}$ Pendidikan Guru Madrasah Ibtidaiyah, IAIN Padangsidimpuan \\ Email : rahmadanitanjung91@gmail.com
}

\begin{abstract}
Abstrak
Jenis penelitian ini adalah penelitian tindakan kelas (PTK) dengan ciri khas yaitu dilaksanakan dengan menggunakan siklus-siklus yang merupakan suatu pemecahan menuju praktek pembelajaran yang lebih baik. Tiap pelaksanaan siklus terdiri dari perencanaan, pelaksanaan, tindakan, observasi dan refleksi. Penelitian dilakukan pada siswa kelas V SD Pudun Jae. Penelitian ini adalah penelitian tindakan kelas dengan jumlah Subjek Penelitian sebanyak 30 orang siswa yang berasal dari siswa kelas V SD Pudun Jae. Metode yang digunakan pada penelitian ini adalah penelitian tindakan kelas. Untuk memperoleh data yang digunakan dalam penelitian ini penulis melakukan tes dan observasi. Adapun teknik analisa data dalam penelitian ini adalah deskripsi kualitatif dengan menguraikan persentase yang digunakan.

Setelah pelaksanaan pre test diperoleh tingkat ketuntasan hasil belajar secara klasikal yaitu ada 6 siswa yang mencapai tingkat ketuntasan belajar dengan presentasi $30 \%$ dan 24 orang siswa tidak tuntas dengan presentasi $70 \%$ dengan nilai rata-rata 47 . Perolehan hasil siklus I dengan menggunakan model pembelajaran Scramble diperoleh tingkat ketuntasan hasil belajar secara klasikal yaitu 20 orang siswa yang mencapai tingkat ketuntasan belajar dengan presentasi $88 \%$ dan tidak tuntas sebanyak 3 dengan presentasi $12 \%$ dengan nilai rata-rata 70 . Perolehan hasil siklus I ditindaklanjuti pada siklus II dengan menggunakan model pembelajaran scramble diperoleh tingkat ketuntasan hasil belajar secara klasikal sebanyak 23 orang siswa yang mencapai tingkat ketuntasan belajar dengan presentasi $100 \%$ dengan nilai rata-rata 84 .

Dengan demikian maka dapat disimpulkan kegiatan pembelajaran dengan menggunakan model pembelajaran Scrambel dapat meningkatkan hasil belajar siswa kelas IV SD Pudun Jae pada pelajaran IPS dalam materi Keanekaragaman Suku Bangsa dan Budaya Indonesia.
\end{abstract}

Kata kunci: Hasil Belajar, Model Pembelajaran Scramble.

\section{PENDAHULUAN}

Pendidikan Ilmu Pengetahuan Sosial sebagai mata pelajaran diterapkan dalam kurikulum di sekolah mulai jenjang Sekolah Dasar (SD), Sekolah Menengah Pertama (SMP), hingga Sekolah Menengah Atas/Kejuruan (SMA/SMK). Pendidikan IPS di jenjang persekolahan erat kaitannya dengan disiplin ilmu sosial yang terintegrasi dengan pengetahuan lain yang dikemas secara ilmiah dan pedagogis untuk kepentingan pembelajaran.

IPS di sekolah pada dasarnya bertujuan mempersiapkan peserta didik sebagai warga negara yang baik (good citizenship). Sebagai warga negara yang baik, peserta didik harus menguasai pengetahuan (knowledge), keterampilan (skills), sikap dan nilai (attitude dan values) yang dapat digunakan untuk memecahkan masalah pribadi maupun sosial serta dapat mengambil keputusan untuk berpartisipasi dalam kegiatan masyarakat di tingkat lokal, regional, maupun global.

Sejak tahun 1970-an, Istilah Ilmu Pengetahuan Sosial mulai dikenal di Indonesia sebagai hasil kesepakatan komunitas akademik. Pengertian IPS dalam istilah asing lebih dikenal dengan nama Social Studies. Pengertian social studies yang paling berpengaruh hingga akhir abad ke-20 
adalah definisi yang dikemukakan Edgar Wesley pada tahun 1937. Wesley mengatakan bahwa "Pendidikan IPS adalah ilmu sosial yang disederhanakan untuk tujuan-tujuan pedagogi. Pendidikan IPS sebagai pendidikan disiplin ilmu dengan bidang kajian eklektik. IPS memiliki kekhasan sebagai pendidikan disiplin ilmu, yakni kajiannya bersifat terpadu (integrated), interdisipliner, dan multidimensional. Pendidikan IPS yang baru dikenalkan dan dikembangkan dalam kurikulum Indonesia di awal tahun 1970-an, kini semakin berkembang, sejalan dengan perkembangan pemikiran di negara maju.

Program pembelajaran IPS harus mampu memberikan pengalaman-pengalaman belajar yang berorientasi pada aktivitas belajar peserta didik, Pelibatan peserta didik dalam aktivitas belajar agar mereka memiliki kemampuan memecahkan masalah dalam lingkungan belajar yang dibuat sebagaimana realitas yang sesungguhnya.

Dengan beberapa alasan tersebut maka pemerintah mencanangkan suatu program dimana pendidikan sekarang harus membangun karakter dalam pembelajaran siswa, baik dalam kehidupan sekolah maupun dikehidupan sehari-hari agar tercermin seorang siswa yang benar-benar memiliki sifat cerdas, terampil, dan bertanggung jawab sehingga apa yang diharapkan oleh pemerintah tentang pembangunan karakter pada diri siswa dapat terlaksana dengan baik.

Dalam proses pembentukan karakter tersebutlah pendidikan IPS berperan penting dalam mengembangkan karakter dimana ikut berperan aktif dalam membangun memberikan pengetahuan yang berhubungan dengan kecerdasan, memberikan pelajaran yang berhubungan dengan nilai-nilai, moral, tanggung jawab dan juga pelajaran yang berhubungan dengan kehidupan sehari-hari baik yang menyangkut dengan pemerintahan sampai kehidupan diri sendiri siswa sebagai mahluk individu dan sosial dalam masyarakat. Sehingga pelajaran pendidikan IPS merupakan refrensi untuk hidup bermasyarakat dan bernegara.

Berdasarkan observasi dan hasil wawancara dengan guru kelas V yang peneliti lakukan di SD Pudun Jae pada di semester 1, masih banyak permasalahan pelaksanaan standar isi mata pelajaran IPS. Guru dalam menerapkan pembelajaran lebih menekankan pada metode yang mengaktifkan guru, guru kurang variatif dalam menggunakan model pembelajaran yaitu pada saat memberikan materi hanya berupa ceramah dan lebih menekankan pada membuat catatan dari buku paket, keaktifan siswa untuk bertanya dan menjawab pertanyaan dalam kegiatan KBM masih belum optimal, sehingga siswa kurang termotivasi untuk belajar dan siswa kurang menguasai materi yang diajarkan. Siswa mengalami kesulitan dalam menjawab soal - soal latihan, baik yang ada di buku maupun yang diberikan oleh guru. Hal ini dapat dilihat dari hasil ulangan harian yang diperoleh siswa tidak sesuai dengan standar ketuntasan belajar siswa. Dimana hasil ulangan yang diperoleh siswa masih dibawah rata-rata KKM (Kriteria Ketuntasan Minimal) yaitu 65. Dari jumlah 23 siswa hanya 7 siswa tuntas hasil belajar dengan presentasi $30,43 \%$, sedangkan 16 siswa belum tuntas dengan presentasi $69,56 \%$ nilai rata-rata di bawah rata-rata KKM. Seharusnya belajar dikatakan tuntas apabila siswa secara 
keseluruhan mampu mendapatkan nilai rata-rata 65. Dengan demikian dapat dikatakan bahwa hasil belajar siswa pada pembelajaran tersebut masih sangat rendah.

Untuk mengatasi masalah dalam pembelajaran tersebut guru perlu menggunakan Scrmable dalam pembelajaran pendidikan kewarganegaraan. Karena model Scramble merupakan model yang baik digunakan untuk meningkatkan hasil belajar siswa. Menurut Suyatno (2009), Scramble merupakan salah satu tipe pembelajaran kooperatif yang disajikan dalam bentuk kartu. Beberapa penelitian yang telah dilakukan mengenai model pembelajaran scramble, salah satunya penelitian yang dilakukan oleh Sri Handayani dkk (2014) dalam judul penelitiannya " Pengaruh Model Penbelajaran Scramble terhadap Hasil Belajar Siswa Kelas VII SMP Negeri 2 Satu Atap Kepenuhan Hulu Tahun Pembelajaran 2014/2015. Berdasarkan hasil analisis data penelitian, maka dapat disimpulkan bahwa terdapat pengaruh model pembelajaran scramble terhadap hasil belajar siswa pada materi keanekaragaman mahluk hidup kelas VII di SMP Negeri 2 Satu Kepenuhan Hulu Tahun

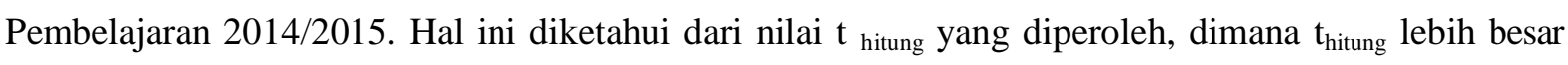
dari $t_{\text {tabel }}(4,44>1,99)$. Dengan demikian, terdapat pengaruh model pembelajaran scramble terhadap hasil belajar siswa pada materi mahlik hidup kelas VII di SMP Negeri 2 Satu Atap Kepenuham Hulu Tahun pembelajaran 2014/2015.

Berdasarkan latar belakang masalah di atas, maka penulis termotivasi untuk melakukan suatu penelitian tindakan kelas dengan judul :

Meningkatkan Hasil Belajar IPS Melalui Model Pembelajaran Scramble Siswa Kelas V SD Pudun Jae pada Materi Keanekaragaman Suku Bangsa dan Budaya Indonesia.

\section{KAJIAN TEORI}

\section{Pengertian Hasil Belajar}

Keberhasilan siswa dalam belajar pendidikan kewarganegaraan dapat dilihat atau diukur dari pencapaian hasil belajarnya. Hal itu sejalan dengan pendapat Dimyati dan Mujdiono (2006:20) bahwa " hasil belajar merupakan suatu puncak dari proses belajar". Hasil belajar tersebut terjadi terutama berkat evaluasi guru.

Hasil belajar dapat diperoleh oleh guru dari perbuatan, nilai-nilai, dan, pengertian-pengertian, sikap-sikap, appersepsi dan keterampilan yang diperoleh dari siswa dalam pembelajaran yang dilakukan dikelas.

Sejalan dengan Gagne (dalam Suprijono 2010:5-7) hasil belajar adalah pola-pola perbuatan, nilai-nilai, pengertian-pengertian, sikap-sikap, apresiasi,dan keterampilan. Hasil belajar berupa:

1). Informasi verbal yaitu kapabilitas mengungkapkan pengetahuan dalam bentuk bahasa, baik lisan maupun tertulis. Kemampuan merespon secara spesifik terhadap rangsangan spesifik. Kemampuan tersebut tidak memerlukan manipulasi simbol,pemecahan masalah maupun penerapan aturan.2). Keterampilan intelektual yaitu kemampuan mempresentasikan konsep dan lambang. Keterampilan intelektual terdiri dari kemampuan mengategorisasikan, 
kemampuan analitis-sintesis fakta-konsep dan mengembangkan prinsip-prinsip keilmuan. Keterampilan intelektual merupakan kemampuan melakukan aktivitas kognitif bersifat khas.3). Strategi kognitif yaitu kecakapan menyalurkan dan mengarahkan aktivitas kognitifnya sendiri. Kemampuan ini meliputi penggunaan konsep dan kaidah dalam memcahkan masalah.4). Keterampilan motorik yaitu kemampuan melakukan serangkaian gerak jasmani dalam urusan dan koordinasi, sehingga terwujud otomatisme gerak jasmani. 5). Sikap adalah kemampuan menerima atau menolak objek berdasarkan penilaian terhadap objek tersebut. Sikap berupa kemampuan menginternalisasikan dan eksternalisasikan nilai-nilai. Sikap merupakan kemampuan menjadikan nilai-nilai sebagai standar perilaku.

Yang harus diingat, hasil belajar adalah perubahan perilaku secara keseluruhan bukan hanya salah satu aspek potensi kemanusian saja. Artinya hasil pembelajaran yang dikategorikan oleh pakar pendidikan sebagaimana tersebut diatas tidak dapat dilihat secara fragmentaris atau terpisah, melainkan komprehensif. (Suprijono, 2010:7)

Perubahan perilaku akibat kegiatan belajar mengakibatkan siswa memiliki penguasaan terhadap materi pengajaran yang disampaikan dalam kegiatan belajar mengajar untuk mencapai tujuan pengajaran. Perubahan prilaku akibat kegiatan belajar dapat diketahui dari hasil belajar siswa.

Sejalan dengan pendapat Purwanto (2011:46) "hasil belajar adalah perubahan perilaku siswa akibat belajar. Perubahan perilaku siswa akibat belajar". Perubahan perilaku disebabkan karena dia mencapai penguasaan atas sejumlah materi yang diberikan dalam proses belajar mengajar. Pencapaian itu didasarkan atas tujuan pengajaran yang telah ditetapkan. Hasil itu dapat berupa perubahan dalam aspek kognitif, afektif, maupun psikomotor.

Menurut Sudjana (2009:3) "hasil belajar siswa pada hakikatnya adalah perubahan tingkah laku. Tingkah laku sebagai hasil belajar dalam pengertian yang luas mencakup bidang kognitif, afektif, dan psikomotoris".

Dalam Kamus Bahasa Indonesia (Ali, 1997:121) menjelaskan bahwa "hasil adalah sesuatu yang diadakan, dibuat, dijadikan". Sedangkan "belajar adalah berusaha, berlatih untuk mendapatkan pengetahuan". Jadi hasil belajar menurut kamus bahasa hasil belajar adalah sesuatu yang diadakan untuk berlatih dalam mendapatkan pengetahuan.

Dari beberapa defenisi di atas maka dapat disimpulkan bahwa hasil belajar adalah perubahan perilaku siswa akibat belajar dan hasilnya dapat berupa perubahan dalam aspek kognitif, afektif, maupun psikomotor.

\section{Faktor-Faktor yang Mempengaruhi Belajar}

Belajar adalah suatu proses yang menimbulkan terjadinya satu perubahan atau pembaharuan dalam tingkah laku atau kecakapan. Sampai dimanakah perubahan itu tercapai atau dengan kata lain berhasil atau tidaknya itu tergantung berbagai faktor yang mempengaruhinya. Dalam hal ini Slameto 
(2010:54) mengemukakan bahwa faktor-faktor yang mempengaruhi belajar dapat digolongkan menjadi dua jenis, yaitu :

(a) faktor internal, yaitu faktor yang berasal dari dalam diri siswa sendiri meliputi dua bagian, yakni: a. faktor jasmaniah meliputi faktor kesehatan dan cacat tubuh dan b. faktor psikologis meliputi kecerdasan, perhatian, minat, bakat, motif, kematangan dan kesiapan. (b) faktor eksternal, yaitu faktor yang berasal dari luar diri siswa dikelompokkan menjadi 3 (tiga) faktor yakni: lingkungan keluarga, faktor lingkungan sekolah dan faktor lingkungan masyarakat.

Selanjutnya Syah (2009:129) menjelaskan bahwa faktor-faktor yang mempengaruhi belajar adalah sebagai berikut: (a) faktor internal yaitu faktor yang berasal dari dalam diri siswa itu sendiri, yang meliputi dua aspek fisiologis yang bersifat jasmaniah dan aspek psikologis yang bersifat rohaniah, terdapat pada diri organisme. (b) faktor eksternal siswa yakni faktor yang berasal dari luar diri siswa, yang terdiri dari dua macam yakni faktor lingkungan sosial (seperti para guru, staf administrasi dan teman-teman sekelas) dan faktor lingkungan sosial (seperti, gedung sekolah dan letaknya, rumah tempat tinggal keluarga siswa, alat-alat belajar, keadaan cuaca, dan waktu belajar yang digunakan siswa). (c) faktor pendekatan belajar yakni jenis upaya belajar siswa yang meliputi strategi dan metode yang digunakan siswa untuk melakukan kegiatan mempelajari materimateri pembelajaran.

Adapun menurut Djaali (2011:101) menyatakan bahwa "faktor-faktor yang mempengaruhi belajar antara lain yaitu motivasi, sikap dalam belajar, minat, kebiasaan belajar dan konsep diri”.

Dengan demikian faktor-faktor yang mempengaruhi belajar siswa di atas akan sangat mempengaruhi hasil belajar siswa tersebut. Ada hasil belajar siswa yang tinggi yang disebut berprestasi tinggi dan hasil belajar siswa yang rendah disebut berprestasi rendah.

\section{Pengertian Model Pembelajaran}

Dalam dunia pendidikan model pembelajaran merupakan hal yang penting untuk diterapkan karena model merupakan suatu penunjang pembelajaran yang baik dilakukan untuk mempermudah guru dalam menyampaikan materinya.

Sejalan dengan pendapat Mils (dalam Suprijono 2010:45-46) bahwa “ Model adalah bentuk representasi akurat sebagai proses aktual yang memungkinkan seseorang atau sekelompok orang mencoba bertindak berdasarkan model itu".

Model merupakan interprestasi terhadap hasil observasi dan pengukuran yang diperoleh dari beberapa sistem. Model pembelajaran merupakan landasan praktik pembelajaran hasil penurunan teori psikologi pendidikan dan teori belajar yang dirancang berdasarkan analisis terhadap implementasi kurikulum dan implikasinya pada tingkat operasional di kelas.

Model Pembelajaran dapat diartikan pula sebagai pola yang digunakan untuk penyusunan kurikulum, mengatur materi, dan memberi petunjuk kepada guru di kelas. Dan disisi lain model 
pembelajaran juga diartikan sebagai pola yang digunakan sebagai pedoman dalam merencanakan pembelajaran dikelas maupun tutorial. Sejalan dengan itu model pembelajaran mengacu pada pendekatan yang akan digunakan.

Hal itu diperkuat dengan pendapat Arends (dalam Suprijono 2010:45-46), menururtnya model pembelajaran mengacu pada pendekatan yang akan digunakan, termasuk didalamnya tujuan-tujuan pembelajaran, tahap-tahap dalam kegiatan pembelajaran, lingkungan pembelajaran, dan pengelolaan kelas. Model pembelajaran dapat didefinisi dalam mengorganisasikan pengalaman belajar untuk mencapai tujuan belajar.

Merujuk pemikiran Joyce (dalam Suprijono 2010:45-46), fungsi model adalah “ each model guides us as we design instruction to help students achine various obejctives." Yang berarti bahwa model pembelajaran berfungsi pula sebagai pedoman bagi para perancang pembelajaran dan para dalam merencanakan aktivitas belajar mengajar. Melalui model pembelajaran guru dapat membantu peserta didik mendapatkan informasi, ide, keterampilan, cara berpikir, dan mengekspresikan ide. Model pembelajaran berfungsi pula sebagai pedoman bagi para perancang pembelajaran dan para guru dalam merencanakan aktivitas belajar mengajar.

Melalui model pembelajaran guru dapat membantu peserta didik mendapatkan informasi, ide, keterampilam, cara berpikir, dan mengekspresikan ide sejalan dengan pengertian menurut Istarani ( 2011: 1) " model pembelajaran adalah seluruh rangkaian penyajian materi ajar yang meliputi segala aspek sebelum sedang dan sesudah pembelajaran yang dilakukan guru serta segala fasilitas yang terkait yang digunakan secara langsung atau tidak langsung dalam proses belajar mengajar".

Dari beberapa pendapat di atas maka dapat disimpulkan bahwa model pembelajaran adalah seluruh rangkaian penyajian materi ajar yang meliputi aspek sebelum sedang dan sesudah pembelajaran serta segala fasilitas yang dapat membantu peserta didik dalam proses belajar mengajar baik untuk menyampaikan informasi, ide, keterampilam, cara berpikir, dan mengekspresikan ide yang dilakukan guru serta segala fasilitas yang terkait yang digunakan secara langsung atau tidak langsung dalam proses belajar mengajar.

Model pembelajaran merupakan rangkaian penyajian materi ajar serta segala fasilitas yang dapat membantu peserta didik dalam proses belajar mengajar ini juga memiliki ciri-ciri atau karakteristik sebagai model pembelajaran menurut Rusman (2010: 136) diantara adalah

(1). Berdasarkan teori pendidikan dan teori belajar dari para ahli tertentu, (2). mempunyai misi atau tujuan pendidikan tertentu,(3). Dapat dijadikan pedoman untuk perbaikan kegiatan belajar mengajar di kelas,(4). Memiliki bagian-bagian model yang dinamakan:a. Urutan langkahlangkah pembelajaran (syintax),b. Adanya prinsip-prinsip reaksi,c. Sistem sosial, d. Sistem pendukung,(5). Memiliki dampak sebagai akibat terapan model pembelajaran,(6). Membuat persiapan mengajar dengan pedoman model pembelajaran yang dipilihnya.

Beberapa macam model pembelajaran yang ada dan dapat digunakan dalam proses 
pembelajaran sesuai dengan kondisi dan kreativitas seorang pengajar, diantaranya adalah : (a). Picture-Picture.(b). Examples Non Examples.(c). Numbered Heads Together.(d). Cooperative Script.(e).Student Teams-Achievement Divisions .(f). Kepala Bernomor Struktur.(g). Jigsaw .(h). Problem Based Intruction.(i). Problem Centered Learning.(j).Mind Mapping.(h).Word Square. (Istarani 2011:7-181)

Diantara banyaknya model pembelajaran yang mana masing-masing memiliki tujuan membantu proses belajar mengajar siswa. Tetapi, yang menjadi model utama dalam penelitian ini adalah model pembelajaran pada point (h) yaitu model pembelajaran scramble yang akan dibahas di bawah ini.

\section{Pengertian Model Pembelajaran scramble}

Model pembelajaran scramble merupakan model pembelajaran dengan metode membagikan lembar berisi soal dan lembar berisi jawaban. Lembar jawaban yang dibagikan tidak hanya satu melainkan disertai beberapa alternatif jawaban lain. Peserta didik diharapkan mampu memasangkan lembar soal dengan lembar jawaban yang benar disertai cara penyelesaiannya.ModelPembelajaran Scramble Pelaksanaan pembelajaran yang dilakukan dalam penelitian ini memiliki beberapa faktor diantaranya mengenai model pembelajaran scramble. Model pembelajaran adalah suatu rencana atau pola yang dapat digunakan untuk membentuk kurikulum (rencana pembelajaran jangka panjang), merencanakan bahan-bahan pembelajaran, dan membimbing pembelajaran di kelas Joyce danWeil (Rusman, 2012: 133). Model pembelajaran merupakan suatu rangkaian dari pendekatan, strategi, metode, teknik, dan taktik pembelajaranSutirman (2013: 22).

Model pembelajaran pada dasarnya merupakan bentuk pembelajaran yang tergambar dari awal sampai akhir yang disajikan secara khas oleh guru. Joice (Trianto, 2007: 2) model pembelajaran adalah suatu perencanaan atau pola yang dapat kita gunakan untuk mendesainpola-pola mengajar secara tatap muka di dalam kelas atau mengatur tutorial, dan untuk menentukan material/perangkat pembelajaran termasuk didalamnya buku-buku, film, tipe, program media komputer, dan kurikulum (sebagai kursus untuk belajar). Arends (Trianto, 2007: 2) menyatakan, "The term teaching model refres to a particular approch to instruction that includes its goals, syntax, environment, and management syestem." Artinya istilah model adalah pengajaran mengarah pada suatu pendekatan pembelajaran tertentu termasuk tujuann, sintak, lingkungan dan sistem pengelolaannya.Berdasarkan beberapa pengertian diatas,dapat disimpulkan bahwa model pembelajaran adalah suatu rencana atau pola yang digunakan dalam kegiatan proses belajar yang tergambar dari awal sampai dengan akhir,disajikan secara khas oleh guru sebagai pedoman pembelajaran di kelas maupun tutorial dengan mengunakan pendekatan pembelajaran berdasarkan tujuan, sintaks, pengeolaan lingkungan kelas.

Rober Taylor (Miftahul, 2013:303) model pembelajaran scramble adalah "salah satu metodepembelajaran yang dapat meningkatkan kosentrasi dan kecepatan serta ketepatan berpikir siswa”. Kokom Komalasari(Fitriana, 2017: 15)scramble berasal dari bahasa Inggris yang berarti 
"perebutan, perjuangan,model pembelajaran scramble mengajak siswa mencari jawaban terhadap suatu pertanyaan secara kreatif dengan cara menyusun huruf-huruf yang disusun secara acak sehingga membentuk suatu jawaban yang tepat dan benar".Scramblemerupakan model pembelajaran yang mengajak siswa menemukan jawaban dan menyelesaikan permasalahan yang ada dengan cara membagikan lembar soal atau lembar jawaban yang tersedia. Model pembelajaran scramblemerupakan metode yang berbentuk permainan acak kata, kalimat, atau paragraf (Sohimin, 2016:166).

Scramble dipakai untuk jenis permainan anak-anak yang merupakan latihan pengembangan dan peningkatan wawasan pemikiran kosakata. Sesuai dengan sifat jawabannya Sohimin (2016:167) menyebutkan bahwa scrambleyang terdiri atas bermacam-macam bentuk yaitu:a) Scramble Kata, yakni sebuah permainan dengan menyusun huruf-huruf yang telah diacak susunannya sehingga membentuk suatu kata yang bermakna, misalnya:A-l-p-j-e-r-a= Pelajar, t-u-k-i-l = kulit. b)Scramble Kalimat, yakni sebuah permainan dengan menyusun kalimat dari kata-kata yang telah diacak. Bentuk kalimat hendaknya logis,bermakna, tepat, dan benar. Contohnya:1)pergi-ibu-pasar-ke Menjadi :Ibu pergi ke pasar.c)Scramble Wacana, yakni permainan menyusun wacana logis danbermakna. Hasil susunan wacana dalam permainan scramble wacana hendaknya logis dan bermakna.d)ScrambleParagraf, yakni sebuah permainan menyusun suatu paragrafberdasarkan kalimat-kalimat acak. Hasil susunan paragraf hendaknya logis, dan bermakna, contohnya:1)Paginya ikut pergi ke pasar membeli sayuran bersama ibu. Sehabis makan aku membantu ibu mencuci piring.3)Setiap hari minggu aku membantu ibu.4)Membantu ibu memasak di dapur. Kalimat acak tersebut disusun menjadi kalimat runtut: Setiap hari minggu aku membantu ibu, membantu ibu memasak di dapur. Paginya ikut pergi ke pasarmembeli sayuran bersama ibu, sehabis makan aku membantu ibumencuci piring.

Berdarkan uraian diatas, dapat disimpulkan bahwa pembelajaran scrambledapat diartikan yaitu sebagai permainan acak kata dengan menggunakan latihan soal serta kartu jawaban acak untuk disusun dengan membentuk rancangan-rancangan agar menjadi kata atau jawaban yang benar. Dalam penelitian ini, peneliti akan memberikan batasan-batasan dalam penelitian. Batasan ini peneliti akan fokusmembahas jenis scramblekata, scramblekata yakni sebuah permainan yang menyusun kata dan huruf yang telah diubah atau dikacaukan letaknya sehingga membntuk suatu kata tertentu yang bermakna.Tabel 2.1Sintaks Model Pembelajaran ScrambleTahap Kegiatan GuruKegiatan Siswa Fase 1Stimulus/pemberian ransangan (Stimulation)Menanyakan kepada siswa tentang pengetahuan atau pengalaman seputar materi.Menyimak pertanyaan yang diberikan oleh guru.Fase 2Pertanyaan/identifikasi masalah (Problem Statement)Guru membimbing siswa untuk mengidentifikasi masalah yang berkaitan dengan materi.Mendengarkan penjelasan guru tentang tujuan pembelajaran.Fase 3Pengumpulan data atau informasi (Data Collection)a.Menyampaikan materi sesuai yang dijabarkan dalam RPP.b.Membagikan kartu soal dan kartu jawaban yang telah diacak susunannya.c.Mendengarkan penjelasan guru tentang tujuan pembelajaran.d.Siswa 
mengerjakan soal sesuai arahan guru.

Tukiran Taniredja, dkk (2014: 116) media dan langkah-langkah yang digunakan dalam model pembelajaran scramble adalahsebagai berikut:a)Buatlah media pertanyaan yang sesuai dengan kompetensi yang ingin dicapai dalam pembelajaran.b)Buat media jawaban yang diacak hurufnya.c)Langkah pertama guru menyajikan materi sesuai kompetensi yang di capai dalam pembelajaran.d)Lengkah kedua membagikan lembar kerja kepadasiswa.Kemudian Langkah-langkah dalam model pembelajaran scramble Miftahul Huda(2013: 304) yaitu sebagai berikut:a)Guru menyiapkan tujuan pembelajaran yang ada pada indikator, menjelaskan materi sesuai topik yaitu mengenai materiporos maritim dunia, kemudian mengeluarkan kata-kata atau kalimat yang terdapat di dalam materi tersebut dalam sebuah kartu-kartu kalimat.b)Guru memberikan kartu soal dan kartu jawaban dengan susunan acak kepada siswa dan siswa mengerjakan soal dengan cara menyusun jawaban yangcocok dengan kartu jawaban yang sebelumnya sudah diacak susunannyakatanya.c)Guru memberikan durasi tertentu kepada siswa untuk mengerjakan soal yang telah diberikan.d)Siswa harus bisa mengerjakan soal dan mencari jawabannya dalam durasi waktu yang sudah ditentukan.e)Setelah selesai mengerjakan soal dan durasi waktu yang diberikan telah habis, siswa mengumpulkan hasil pekerjaan.f)Guru mengoreksi dan memberikan nilai sesuai dengan hasil yang dikerjakan oleh siswayang maju kedepan untuk menjawab soal dengan ketentuan jawaban tepat dan cepat dan paling banyak benar.Adapun langkah-langkah dalam model pembelajaran scrambleAris Sohimin (2017: 167)yaitu sebagai berikut:1)PersiapanPada tahap ini guru menyiapkan bahan dan media yang akan digunakan dalam pembelajaran. Media yang digunakan berupa kartu soal dan kartu jawaban, yang sebelumnya jawaban telah diacak susunannya sedemikian rupa. Kemudian guru menyiapkan kartukartu sebanyak kelompok yang telah dibagidan berdasarkan jumlah sisiwa dalam kelompok. Guru mengatur hal-hal yang mendukung proses belajar mengajar mengatur tempat duduk sesuai kelompok yang telah dibagi ataupun memeriksa kesiapan siswa belajar.2)Kegiatan IntiMenjelaskan materi sesuai topik pembelajaran. Kegiatan dalam tahap ini adalah setiap masing-masing kelompok melakukan diskusi untuk mengerjakan soal dan mencari kartusoal untuk jawaban yang cocok. Melakukan diskusi kelompok besar untuk

18menganalisis dan mendengar hasil kerja yang telah disepakati kemudian membandingkan dan mengkaji jawaban yang benar.3)Tindak LanjutKegiatan tindak lanjut tergantung dari hasil belajar siswa. Contoh, pemberian tugas serupa dengan bahan yang berbeda.

Pendapat lain yaitu Istarani (2014: 187), berpendapat bahwa kelebihan pembelajaran scrambleantara lain:a)Dapat mempermudah siswa dalam menguasai bahan ajar, sebab siswa hanya melengkapi suatu pertanyaan dimana jawabannya sudah dipisahkan hanya saja siswa tinggal mencocokannya.b)Dapat mempermudah guru dalam menyampaikan materi ajar, sebab dengan merujuk pada kertas kerja yang telah ditentukan siswa akan mempelajarinya secara seksama.c)Meningkatkan motivasi belajar siswa, karena dilengkapi dengan kertas kerja yang telah dipersiapkan sebelumnya.d)Melatih siswa untuk berpikir secara kritis, sebab tanpa adanya pikiran 
yang kritis, siswa tidak akan mampu melengkapi pertanyaan sesuai yang diinginkan.Berdasarkan pendapat di atas, bahwa pembelajaran scramblememiliki kelebihan lain dibandingkan model pembelajaran lainnya. Model pembelajaran ini sangat tepat untuk diterapkan dalam proses pembelajaran geografi terutama pada materi poros maritim duniaagar dapat membantu ketepatan dan kecepatan siswa untuk berpikir aktifdalam menjawab soal, kreatif dan hasil yang maksimalberdasarkan skor jawaban terbanyak dan tercepat.4.Kekurangan Model Pembelajaran ScrambleKekurangan atau kelemahan model pembelajaran scramble(Miftahul Huda, 2016: 306)yaitu:a)Terkadang dalam mengimplementasikannya, memerlukan waktu yang panjang sehingga guru sulit menyesuaikan dengan waktu yang telah ditentukan.b)Siswa menerima bahan mentah yang hanya perlu diolah dengan baik.Kelemahan selanjutnya yaitu yang dikemukakan oleh Aris Shoimin (2016: 168) mengemukakan bahwa:a)Pembelajaran ini terkadang sulit dalam merancangnya karena terbentur dengan kebiasaan siswa dalam belajar.

20b)Terkadang dalam mengimplementasikannya, memerlukan waktu yang panjang sehingga guru suit menyesuaikan dengan waktu yang terlalu ditentuakan.c)Selama kriteria keberhasilan belajar ditentukan oleh kemampuan siswa menguasai materi pelajaran, pembelajaran ini akan sulit diimplementasikan guru.d)Metode permainan ini biasanya menimbulkan suara gaduh. Hal ini jelas mengganggu kelas yang berdekatan.Selanjutnya Istarani (2014: 187) berpendapat, kelemahan model pembelajaran scrambleadalah:a)Akan sulit bagi guru bila materi yang disampaikan pengenalan awal.b)Sulit bagi guru yang kurang paham tentang kisi-kisi pembuatan soaldengan model pembelajaran scramble.c)Ditemukan adanya ketidak cocokan antara pernyataan dengan kelengkapan kata jawaban.d)Siswa merasa model ini bukan belajar, tetapi sekedar bermain-main.Beberapa pendapat diatas,menunjukan bahwa kelemahan yang biasanya terdapat pada model pembelajaran scrambleadalah siswa bisa saja mencontek jawaban temannya, malas untuk berpikir kritis, siswa tidak dilatih untuk berpikir kreatif,karena jawaban sudah tersedia.

\section{Hipotesis Penelitian}

Hipotesis merupakan jawaban sementara yang kebenarannya perlu diuji secara empiris. Hipotesis dalam penelitian ini adalah " dengan menggunakan model pembelajaran scramble dapat meningkatkan hasil belajar IPS siswa pada materi keanekaragaman suku bangsa dan budaya dikelas V SD Pudun Jae".

\section{METODE PENELITIAN}

Jenis penelitian ini adalah penelitian tindakan kelas (PTK) dengan ciri khas yaitu dilaksanakan dengan menggunakan siklus-siklus yang merupakan suatu pemecahan menuju praktek pembelajaran yang lebih baik. Tiap pelaksanaan siklus terdiri dari perencanaan, pelaksanaan, tindakan, observasi dan refleksi. Penelitian dilakukan pada siswa kelas V SD Pudun Jae. Sebagai subjek dalam penelitian ini adalah siswa kelas V SD pudun jae sebanyak satu kelas yang berjumlah 30 orang terdiri dari 19 siswa perempuan dan siswa laki-laki 11. Model pembelajaran Scramble Menurut Hesti Damayanti (2010: 34), adalah model pembelajaran yang menggunakan penekanan latihan soal yang dikerjakan secara 


\section{Rahmadani Tanjung}

berkelompok yang memerlukan adanya kerjasama antar anggota kelompok dengan berfikir kritis sehingga dapat lebih mudah dalam mencari penyelesaian soal.

Hasil belajar adalah perubahan yang mengakibatkan manusia berubah dalam sikap dan tingkah lakunya dengan melihat proses pembelajaran yang dari tidak tahu menjadi tahu yang pembahasannya dilihat dari kemampuan kognitif, afektif, dan, psikimotor individu tersebut dan berbagai faktor yang mendukung proses belajar baik dari dalam diri siswa dan dari luar diri siswa.

\section{Desain Penelitian}

Penelitian ini dilaksanakan dalam kelas meliputi kegiatan Pelaksanaan Tindakan Kelas (PTK) berupa kegiatan refleksi awal dan melakukan observasi untuk mengidentifikasi permasalahan yang terjadi di kelas, perencanaan pembelajaran, pelaksanaan tindakan, observasi dan refleksi. Pelaksanaan Penelitian Tindakan Kelas (PTK) dilakukan sebanyak 2 siklus dan masing-masing siklus dilakukan dengan 2 kali pertemuan dan pada setiap akhir siklus dilakukan tes untuk mengetahui hasil belajar siswa.

Adapun model dan penjelasan untuk masing-masing tahap adalah sebagai berikut.

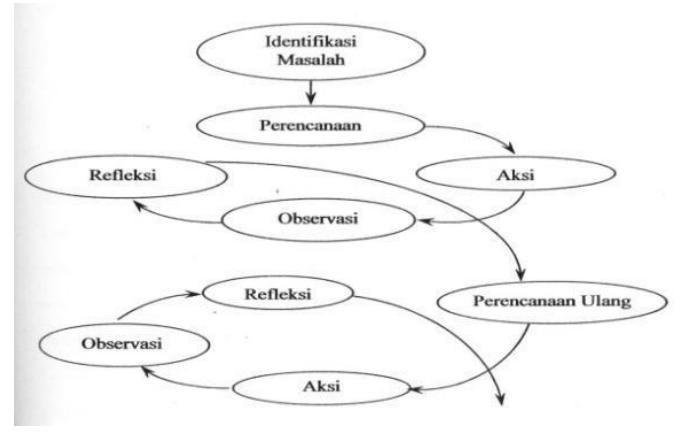

Gambar 2. Penelitian Tindakan Model Hopkins

( dalam Arikunto, 2010:105)

\section{Prosedur Penelitian}

\section{Siklus I}

1. Perencanaan Siklus I

Pada tahap perencanaan siklus I peneliti merancang perencanaan tindakan, antara lain :

- Menyusun rencana pembelajaran dalam bentuk RPP terdiri dari standar kompetensi, konpetensi dasar, tujuan pembelajaran, dan langkah-langkah pembelajaran menggunakan medel scramble.

- Menyusun skenario Scramble pada materi pokok keanekaragaman suku bangsa dan budaya.

- Menyusun format lembar observasi tantang aktivitas siswa dan pelaksanaan pembelajaran yang dilakukan guru.

- Menyusun tes untuk mengukur hasil belajar siswa pada materi sistem pemerintahan tingkat pusat 


\section{Pelaksanaan Tindakan Siklus I}

Pada tahap ini dilaksanakan pembelajaran yang sesuai dengan skenario yang sudah disusun yaitu menggunakan model scramble, kegiatan yang dilakukan pada tahap ini adalah:

1. Kegiatan awal

a. Guru melakukan apersepsi (pemberian pre test kepada siswa).

b. Guru memberikan motivasi dan menyampaikan tujuan pembelajaran kepada siswa.

2. Kegiatan Inti

a. Guru menyampaikan kompetensi yang ingin dicapai.

b. Guru memerintahkan siswa untuk membaca dan memahami pengertian sistem pemerintahan pusat.

c. Guru bertanya jawab tentang keanekaragaman suku bangsa dan budaya

d. Guru membagikan lembar kerja scramble kepada siswa

e. Guru membagikan lembar kegiatan dan menjelaskan bagaimana lembaran kegiatan atau langkah-langkah pengerjaan kegiatan scramble kepada siswa.

f. Setelah menjelaskan lembar kegiatan atau langkah-langkah pengerjaan kegiatan kepada siswa guru membagikan copy-an lembar kerja scramble.

g. Siswa diberikan waktu untuk mengerjakan lembar kerja scramble tersebut.

h. Guru memberikan poin setiap jawaban dalam kotak.

3. Kegiatan Akhir

a. Guru mengulangi/ menjelaskan kembali materi yang sekiranya belum dipahami siswa.

b. Siswa dan guru bersama-sama menyimpulkan materi pelajaran yang telah dipelajari.

c. Siswa diberikan tugas untuk mengerjakan soal.

Pada akhir tindakan ini dilakukan tes hasil belajar tentang sejauh mana kemampuan siswa dalam memahami materi yang telah diajarkan.

\section{Observasi Siklus I}

Observasi yang dilakukan meliputi implementasi dan monitoring pada proses pembelajaran di kelas secara langsung. Kegiatan ini yang diamati meliputi aktivitas guru dan siswa dalam pembelajaran. Observasi ini bertujuan untuk mengetahui kesesuaian tindakan dengan rencana yang telah disusun dan guna mengetahui sejauh mana pelaksanaan tindakan dapat menghasilkan perubahan yang sesuai dengan yang dikehendaki. Sekaligus mencatat masalah - masalah yang terjadi dalam pembelajaran.

\section{Refleksi Siklus I}

Kegiatan refleksi dilakukan dengan mempertimbangkan pedoman mengajar yang dilakukan serta melihat kesesuaian yang dicapai dengan yang diinginkan dalam pembelajaran yang pada akhirnya ditemukan kelemahan dan kekurangan untuk kemudian diperbaiki dalam siklus kedua. Setelah siklus pertama dilakukan dan belum maksimal, maka dalam hal ini dilaksanakan siklus II 
dengan tahapan yang sama sebagai berikut:

\section{Siklus II}

\section{Perencanaan Siklus II}

Berdasarkan hasil pengamatan peneliti dan observator selama pelaksanaan tindakan pada siklus I, dapat diidentifikasi maalah-masalah baru yang merupakan pengembangan dari masalah sebelumnya. Selanjutnya dilakukan perencanaan ulang untuk melakukan perbaikan pembelajaran. Adalah tindakan perencanaan antara lain:

- Melakukan perbaikan dan pengembangan skenario pembelajaran berupa rencana pelaksanaan pembelajaran (RPP).

- Menyusun format atau lembar observasi terdiri dari lembar observasi kegiatan pelaksanaan tindakan.

- Menyusun tes untuk mengukur keberhasilan belajar siswa. Sebagai pedoman observer yang dilakukan oleh peneliti dan observer.

- Mengerjakan lembar kerja siswa materinya mengenai sistem pemerintahan. Dan sebagai observernya adalah guru.

\section{Pelaksanaan Tindakan Siklus II}

Pada tahap ini dilaksanakan pembelajaran yang sesuai dengan skenario yang sudah disusun yaitu menggunakan model scramble, kegiatan yang dilakukan pada tahap ini adalah:

1. Kegiatan awal

a. Guru melakukan apersepsi

b. Guru memberikan motivasi dan menyampaikan tujuan pembelajaran siswa.

2. Kegiatan Inti

a. Guru menyampaikan kompetensi yang ingin dicapai.

b. Guru memerintahkan siswa untuk membaca dan memahami pengertian sistem pemerintahan pusat.

c. Guru bertanya jawab tentang lembaga-lembaga negara tingkat pusat

d. Guru membagikan lembar kerja scramble kepada siswa

e. Guru membagikan lembar kegiatan dan menjelaskan bagaimana lembaran kegiatan atau langkah-langkah pengerjaan scramble kepada siswa.

f. Setelah menjelaskan lembar kegiatan atau langkah langkah pengerjaan kepada siswa guru membagikan copy-an lembar kerja scramble.

g. Siswa diberikan waktu untuk mengerjakan lembar kerja scramble tersebut.

h. Guru memberikan poin setiap jawaban dalam kotak.

\section{Kegiatan Akhir}

d. Guru mengulangi/ menjelaskan kembali materi yang sekiranya belum dipahami siswa.

e. Siswa dan guru bersama-sama menyimpulkan materi pelajaran yang telah dipelajari. 
f. Siswa diberikan tugas untuk mengerjakan soal.

Pada akhir tindakan ini dilakukan tes hasil belajar tentang sejauh mana kemampuan siswa dalam memahami materi yang telah diajarkan.

\section{Observasi Siklus II}

Observasi yang dilakukan meliputi monitoring pada proses pembelajaran di kelas secara langsung. Kegiatan yang diamati meliputi aktifitas guru dan siswa dalam pembelajaran. Observasi ini bertujuan untuk mengetahui kesesuaian tindakan dengan rencana yang telah disusun dan guna mengetahui sejauh mana pelaksanaan tindakan dapat menghasilkan perubahan yang sesuai dengan yang dikehendaki. Observasi ini untuk melihat apakah kondisi belajar mengajar dikelas sudah terlaksana sesuai dengan program yang diberikan.

\section{Refleksi Siklus II}

Kegiatan refleksi yang dilakukan untuk mempertimbangkan pedoman mengajar yang dilakukan serta melihat kesesuaian yang dicapai dengan yang diinginkan dalam pembelajaran yang dilakukan pada siklus I, pada akhirnya ditemukan kelemahan dan kekurangan tersebut pada siklus II sudah berkurang.

\subsection{Teknik Pengumpul Data}

Alat yang dipergunakan untuk pengumpulan data yang dibutuhkan dalam penelitian ini terdiri dari tes hasil belajar dan format lembar observasi.

1. Tes Hasil Belajar

Tes dipergunakan untuk mengetahui hasil belajar siswa setelah diberikannya tindakan I dan

Siklus II. Test yang dipergunakan dalam penelitian ini adalah bentuk uraian atau essai.

2. Format Lembar Observasi

Selain tes hasil belajar digunakan lembar observasi untuk mengetahui kesesuaian tindakan dengan rencana yang telah disusun. Lembar format observasi terdiri dari:

a. Lembar observasi aktivitas siswa selama pembelajaran berlangsung

b. Lembar observasi pelaksanaan pembelajaran yang dilakukan oleh peneliti.

\section{Teknik Analisis Data}

Analisis data ini digunakan untuk mengetahui berhasil atau tidaknya tindakan yang dilakukan dalam penelitian ini. Hal ini dilihat seberapa persenkah tingkat keberhasilan yang dicapai dilihat dari perubahan siswa dalam menyerap materi pelajaran.

1. Untuk menganalisis data yang diperoleh dari hasil tes dapat digunakan rumus:

a. Daya serap individu

$$
\mathrm{Sk}^{\mathrm{B}}-\mathrm{x}_{100 \quad(\text { Sudjana, 2009:54) }}
$$

Keterangan:

Sk $\quad$ : Nilai Siswa 


$$
\begin{array}{ll}
\text { B } & \text { : Skor yang diperoleh siswa } \\
\mathrm{N} & \text { : Skor total }
\end{array}
$$

b. Ketuntasan Belajar Individu

$$
\mathrm{PPH}^{\mathrm{B}}-\mathrm{x} 100 \quad \text { (Sudijono, 2008:318) }
$$

Keterangan:

$$
\begin{array}{ll}
\text { PPH } & : \text { Persentase Penilaian Hasil } \\
\text { B } & : \text { Skor yang diperoleh siswa } \\
\mathrm{N} & : \text { Skor total }
\end{array}
$$

Kriteria:

$$
\begin{aligned}
& 0 \leq \mathrm{PPH} \leq 65 \quad \text { Siswa belum tuntas dalam belajar } \\
& 65 \leq \mathrm{PPH} \leq 100 \text { Siswa sudah tuntas dalam belajar }
\end{aligned}
$$

Dari uraian di atas dapat diketahui siswa yang belum tuntas belajar dan yang sudah tuntas belajar secara individu. Selanjutnya dapat juga diketahui apakah ketuntasan belajar secara klasikal telah tercapai, dilihat dari persentase siswa yang sudah tuntas dalam belajar dapat dirumuskan sebagai berikut:

\begin{tabular}{|c|c|}
\hline $\begin{array}{l}\text { Tingkat Keberhasilan } \\
(\%)\end{array}$ & Arti \\
\hline $80-100 \%$ & Sangat tinggi \\
\hline $60-79 \%$ & Tinggi \\
\hline $40-59 \%$ & Sedang \\
\hline $20-39 \%$ & Rendah \\
\hline$<20 \%$ & Sangat rendah \\
\hline
\end{tabular}

2. Ketuntasan Belajar Klasikal

Untuk mengetahui persentase siswa yang sudah tuntas belajar secara klasikal digunakan rumus:

$$
\mathrm{PKK}^{\mathrm{T}}-\mathrm{x} 100 \quad \text { ( ainal Aqib, 2009:41) }
$$

Keterangan:

$$
\begin{array}{ll}
\text { PKK } & \text { : Persentase Keberhasilan Klasikal } \\
\mathrm{T} & : \text { Banyak siswa yang } \mathrm{PPH} \geq 65 \\
\mathrm{~N} & : \text { Banyak subjek penelitian }
\end{array}
$$

\section{Tabel 1.}

\section{Kriteria Tingkat Keberhasilan Siswa dalam \%}


Seorang siswa dikatakan tuntas jika PPH $\geq 65$, sedangkan suatu kelas dikatakan tuntas jika PKK $\geq$ $80 \%$.

Dari persentase di atas dapat diketahui seberapa besar perubahan yang dihasilkan mulai dari awal penelitiam hingga akhir penelitian dan mengetahui bagaimana implementasi penggunaan model pembelajaran Scramble terhadap peningkatan hasil belajar siswa dalam pembelajaran IPS.

2. Observasi

Dalam penelitian ini peneliti membuat lembar observasi untuk siswa dan guru. Lembar observasi ini guna melihat keadaan siswa dan guru selama pembelajaran dan menganalisis hasil observasi adalah deskripsi data setiap aspek observasi.

\section{HASIL PEMBAHASAN}

Setelah kita membahas beberapa hal, baik yang berupa teori maupun yang berupa temuan hasil dari lapangan, maka dalam bagian ini tibalah saatnya peneliti untuk mengambil suatu kesimpulan yang barang kali bisa kita gunakan untuk mengemukakan suatu saran, guna meningkatkan kualitas pendidikan terutama pendidikan IPS di sekolah dasar. Adapun kesimpulan dan saran yang dapat saya utarakan dalam penelitian ini adalah:

Beberapa kesimpulan yang dapat ditarik dari hasil penelitian ini adalah:

1. Setelah pelaksanaan pre test diperoleh tingkat ketuntasan hasil belajar secara klasikal yaitu ada 6 siswa (30\%) yang mencapai tingkat ketuntasan belajar dengan nilai rata-rata 47.

2. Setelah pelaksanaan siklus I dengan menggunakan model pembelajaran scramble diperoleh tingkat ketuntasan hasil belajar secara klasikal yaitu 20 orang siswa $(80 \%)$ yang mencapai tingkat ketuntasan belajar dengan nilai rata-rata 67.

3. Setelah pelaksanaan siklus II dengan menggunakan model pembelajaran scramble diperoleh tingkat ketuntasan hasil belajar secara klasikal sebanyak 23 orang siswa (100\%) yang mencapai tingkat ketuntasan belajar dengan nilai rata-rata 84 .

4. Dengan demikian maka dapat dikatakan penerapan model pembelajaran scramble dapat meningkatkan hasil belajar siswa pada pokok bahasan sistem pemrintahan pusat.

\section{DAFTAR PUSTAKA}

Arikunto, Suharsimi. 2010. Penelitian Tindakan Kelas. Jakarta: PT Bumi Aksara Aqib, Zainal, dkk. 2011. Penelitian Tindakan Kelas. Bandung: CV.Yrama Widya Aunurahman.2013.Belajar dan pembelajaran. Bandung: Alfabeta

Dimyati dan Mudjiono. 2006. Belajar dan Pembelajaran. Jakarta: Rineka Cipta.

Damayanti, Hesti (2010) pengaruh pembelajaran matematika dengan strategi scramble dan make a match terhadap prestasi belajar matematika pada segi empat ditinjau dari motivasi belajar siswa kelas vii semester ii smp n 2 kartasura. Skripsi thesis, Universitas Muhammadiyah 
Surakarta .

Hariono, D. 2014. Pengaruh Model Pembelajaran Kooperatif Tipe Scramble Terhadap Hasil Belajar Peserta didik Mata Pelajaran Fisika Pada Topik Listrik AC-DC. Other thesis, Universitas Negeri Gorontalo

Istarani. 2011. 58 Model Pembelajaran Inovatif. Medan: Media Persada.

Prawiradilaga, Dewi S. 2009. Prinsip disain pembelajaran. Jakarta:Kencana.

Purwanto, M.P. 2011. Evaluasi Hasil Belajar. Yogyakarta: Pustaka Pelajar.

Qudsi FT, Istianah. 2017. Meningkatkan Aktivitas Belajar Fisika dengan “MOSCRA”. Jurnal Guru Dikmen, Vol. 2, No.1 . Jakarta

Slameto. 2010. Belajar dan Faktor Faktor yang Mempengaruhinya. Jakarta: Rineka Cipta.

Shoimin, A. 2014. 68 Model Pembelajaran Inovatif dalam Kurikulum 2013. Yogyakarta: Ar-Ruuz Media.

Syah, Muhibbin. 2009. Psikologi Belajar. Jakarta: PT. Raja Grafindo Persada.

Sudjana, Nana.2009. Penilaian Hasil Proses Belajar Mengajar. Bandung: PT Remaja Rosdakarya.

Supartik. 2012. Pengembangan Bahan Pembelajaran Sains Berbasis Rekayasa untuk Anak Usia Dini ( PAUD) Negeri Pembina 2 Kota Tebing Tinggi Tahun Pelajaran 2011-2012.Tesis. Medan: Universitas Negeri Medan.

Susanto, Ahmad.2014. Pengembangan Pembelajaran IPS di Sekolah Dasar. Jakarta: Kencana. Surapranata, Sumarna.2009.Analisis, Validitas, Reliabilitas dan Interpretasi Hasi. Tes. Bandung:

Remaja Rosdakarya.

Suprijono, Agus. 2010. Cooperative Learning. Yogyakarta: Pustaka Pelajar.

Sardiman. 2008. Interaksi dan Motivasi Belajar Mengajar. Jakarta: Rajawali Pers.

Suyono, dkk.2014.Belajar dan Pembelajaran. Bandung: PT. Remaja Rosdakarya.

Suyatno.2009. Menjelajah pembelajaran Inovatif.Sidoarjo:Masnedi Buana Pustaka.

Susanti Ahmad.2016. Teori Belajar Pembelajaran di Sekola Dasar.Jakarta: Kencana

Sudijono, Anas. 2008. Pengantar Evaluasi Pendidikan. Jakarta: PT. Raja Grafindo Persada

Trianto.2011.Mendesain Model Pembelajaran Iinovatif Progresif. Jakarta: Kencana Predana Media Group.

Triyono, Bruri, dkk. 2009. Pengembangan Bahan Ajar. AKMIL: Mangelang.

Uno, Hamzah. 2011. Model Pembelajaran. Jakarta: Bumi Aksara. 